\title{
PENYERAPAN TENAGA KERJA PADA PROYEK PENAWARAN MODAL DALAM NEGERI DI PROPINSI MALUKU
}

\author{
Ummi Duwita \\ Universitas Pattimura \\ um.duwita@ymail.com
}

\begin{abstract}
This study aims to find out the amount of absorption of labor on the project in the province of Maluku domestic investment PMDN. However, the absorption of labour not only become the main focus of this analysis. The analysis method used is a quantitative method. Where quantitative aspect such us. the number of projects were analyzed, and production capacity of absorption of labor. Results of the analysis show that capital investment projects in the country directly to the addition of the influential budget development, capital investment projects In the country (PMDN) is also very influential in open employment opportunities as well as absorption of manpower there during the years 2005-2010 although absorption showed fluctuations. Therefore, it needs to be improved promotion-promotion of potential areas by Maluku Province for easy BKPMD is known by both national and Foreign investors so that there is a motivation from them to infuse capital in Maluku.
\end{abstract}

Keywords: Employment; PMDN's Project; Production Capacities.

\begin{abstract}
Abstrak
Penelitian ini bertujuan untuk mengetahui jumlah penyerapan tenaga kerja pada proyek PMDN di provinsi Maluku. Namun, penyerapan tenaga kerja tidak hanya menjadi fokus utama analisis ini. Metode analisis yang digunakan adalah metode kuantitatif. Dimana aspek kuantitatif yaitu jumlah Proyek dianalisis, dan kapasitas produksi dari penyerapan tenaga kerja. Hasil analisis menunjukkan bahwa proyekproyek penanaman modal dalam negeri berpengaruh langsung ke penambahan anggaran pembangunan berpengaruh, proyek PMDN juga sangat berpengaruh dalam kesempatan kerja terbuka serta penyerapan tenaga kerja di sana selama tahun 20052010 meskipun penyerapan menunjukkan fluktuasi. Oleh karena itu, perlu ditingkatkan promosi-promosi potensi daerah oleh Provinsi Maluku untuk BKPMD mudah dikenal oleh investor nasional dan asing sehingga ada motivasi dari mereka untuk menanamkan modalnya di Maluku.
\end{abstract}

Kata Kunci: Tenaga Kerja, Proyek PMDN, Kapasitas Produksi.

Diterima: 7 Juni 2013; Direvisi: 17 Juli 2013; Disetujui: 23 Juli 2013 


\section{PENDAHULUAN}

Perkembangan jumlah penduduk Daerah Maluku menurut pelaksanaan sensus tahun 1961, 1971, 1990 dan 2008 berturut-turut : 847.930 jiwa, 1.089 .511 jiwa, 1.157 .558 jiwa dan 1.350.196 jiwa. Jumlah penduduk yang besar ini merupakan modal dasar pembangunan yang cukup besar apabila dilibatkan dalam proses pembangunan, tetapi apabila penduduk tidak dilibatkan dalam pembangunan justru akan menghambat proses pembangunan itu sendiri. Keterlibatan penduduk dalam proses pembangunan dapat terealisasi apabila mereka dapat terserap pada berbagai lapangan kerja yang tersedia.

Hal ini merupakan permasalahan yang dihadapi pemerintah daerah, sebabnya dengan adanya pertumbuhan penduduk yang terus meningkat juga meningkatkan angka pengangguran. Untuk itu maka pemerintah berupaya untuk meningkatkan pembangunan dengan lebih menitikberatkan pada sektor yang banyak menyerap tenaga kerja.

Pengembangan kesempatan kerja di Daerah Maluku merupakan salah satu sasaran yang senantiasa ingin dicapai dalam setiap langkah pembangunan. Pengembangan kesempatan kerja di Daerah Maluku merupakan implikasi dari paling sedikit empat karakteristik kependudukan yang paling terkait yaitu :

- Pertambahan penduduk yang cepat.

- Distribusi yang tidak merata.

- Piramida penduduk muda.

- Mobilisasi penduduk atau sebagian besar penduduk pada golongan umur muda yang tinggi.

Karakteristik tersebut merupakan satu kesatuan dan menimbulkan berbagai permasalahan khususnya perihal kesempatan kerja. Dengan demikian setiap kebijakan pembangunan yang dilaksanakan pada setiap Pelita lebih diarahkan pada pemecahan masalah kesempatan kerja. Hal ini terlihat dari setiap program dan proyek pembangunan yang di rencanakan.

Namun semua ini dapat dilaksanakan apabila ada dukungan dari berbagai pihak, sebab keterbatasan anggaran pembangunan dari sektor pemerintah maka sangat di harapkan dukungan dari swasta. Untuk itulah maka dewasa ini terlihat adanya kelonggaran-kelonggaran yang diberikan pemerintah pusat maupun daerah kepada 
pihak swasta untuk membuka usaha diberbagai bidang, antara lain berupa proyekproyek Penanaman Modal Dalam Negeri (PMDN) maupun dalam bentuk proyekproyek Penanaman Modal Asing (PMA), selama tidak bertentangan dengan undangundang atau peraturan yang berlaku. Pembangunan proyek-proyek PMDN di samping mendatangkan keuntungan bagi negara atau daerah berupa pendapatan yang diterima juga membawa dampak positif dalam membuka kesempatan kerja serta penyerapan tenaga kerja.

Untuk Daerah Maluku pengembangan proyek PMDN sudah mulai dilaksanakan sejak tahun 1970 yaitu PT. Poleko Trading Car yang berlokasi di daerah Maluku Utara (P.Obi) dan bergerak di bidang usaha kehutanan berupa pengelolahan kayu logs. Dengan adanya keringanan dan peluang yang diberikan pemerintah kepada pihak swasta dalam menanamkan modalnya dan mengembangkan usahanya maka sampai dengan tahun 2005 sudah dibangun 95 proyek /Perusahaan dengan 7 bidang usaha yang dilakukan. Sedangkan tahun 2010 telah dibangun 16 proyek atau perusahaan dengan 10 bidang usaha yang dilakukan.

Selanjutnya banyaknya proyek dirinci berdasarkan bidang usaha yang dilakukan, dapat diuraikan sebagai berikut :

1. Bidang Usaha Perkebunan 2 proyek/perusahaan.

2. Bidang Usaha Perikanan 3 proyek/perusahaan

3. Bidang Usaha Kehutanan 1 proyek/perusahaan.

4. Bidang Usaha Galangan Kapal 1 proyek/perusahaan.

5. Bidang Usaha Pengangkutan 2 proyek/perusahaan.

6. Bidang Usaha Perumahan 2 proyek/perusahaan.

7. Bidang Usaha Pariwisata 2 proyek/perusahaan.

8. Bidang Usaha Jasa lainnya 3 proyek/perusahaan.

Proyek-proyek tersebut tersebar di berbagai daerah Propinsi Maluku. Adapun jenis kegiatan masing-masing bidang usaha antara lain :

a) Pengangkutan menyangkut angkutan barang dan orang.

b) Bidang Usaha jasa lainnya meliputi pergudangan atau perdagangan.

c) Jenis bidang usaha kawasan usaha wisata meliputi jasa rekreasi dan hiburan.

d) Bidang usaha galangan kapal dengan jenis usaha perawatan dan perbaikan kapal. 
Menyangkut besarnya kapasitas produksi dan penyerapan tenaga kerja pada proyekproyek PMDN di daerah Maluku selama tahun 2005-2010 rencana pelaksanaan sesuai ijin PMDN yang dikeluarkan pemerintah daerah maka rata-rata realisasi pertahun masih berfluktuatif dimana tahun 2005 direncanakan sebanyak 113 proyek dan realisasi hanya 95 proyek atau $84,07 \%$ serta tahun 2010 direncanakan 26 proyek dan realisasinya 16 proyek atau $61,55 \%$. Dengan demikian belum semua target proyek PMDN melakukan usahanya.

Berdasarkan perkembangan di atas, maka dapatlah dijelaskan bahwa jumlah proyek PMDN di daerah Maluku menunjukkan perkembangan yang berfluktuatif pada 3 tahun terakhir (2008-2010). Namun berbeda halnya dengan penyerapan tenaga kerja, tahun 2006 jumlah tenaga kerja yang terserap sebanyak 21.394 tenaga kerja dan menurun pada tahun 2010 menjadi 9.821 tenaga kerja. Hal tersebut disebabkan karena perkembangan jumlah bidang usaha serta kapasitas produksi dari proyek-proyek tersebut juga berbeda.

Proyek-proyek PMDN merupakan unit usaha yang banyak menyerap tenaga kerja di daerah Maluku. Namun demikian masih kurangnya atau rendahnya tenaga kerja yang terserap pada proyek-proyek PMDN yang telah ditargetkan, padahal saat ini masalah yang dihadapi pemerintah daerah adalah masalah pengangguran sebagai akibat terbatasnya lapangan kerja.

Apabila sumber daya alam ini diolah dan dimanfaatkan oleh pemerintah maka dapatlah mendatangkan pendapatan yang besar serta dapat menyerap tenaga kerja, sehingga dapat mengatasi pengangguran yang ada. Namun demikian dalam upaya untuk mengelola sumber daya alam tersebut pemerintah masih terbatas dengan anggaran atau dana yang ada, sehingga sangat dibutuhkan peranan dari pihak swasta yang diantaranya adalah melalui proyek-proyek PMDN.

Pengkajian tentang peranan penduduk sebagai sumber daya manusia dalam pembangunan ekonomi, merupakan hal yang sangat mendasar mengingat penduduk adalah subjek pembangunan. Sagir (1990), menyatakan bahwa penduduk adalah manusia dalam pengertian perorangan atau kelompok yang bertempat tinggal di suatu wilayah tertentu, oleh karena itu penduduk merupakan suatu kelompok organisme yang terdiri dari individu yang sejenis dan mendiami suatu daerah dengan batas tertentu." 
Dalam kaitannya dengan tersebut diatas, maka tenaga kerja juga merupakan bagian dari penduduk, Lembaga Demografi FE - UI (1980) dalam buku kependudukan Mendefenisikan mendefinisikan Tenaga Kerja ialah jumlah seluruh penduduk dari suatu negara yang dapat memproduksi barang dan jasa mau berpartisipasi di dalam aktivitas tersebut."

Dari batasan tersebut diatas terlihat bahwa lebih ditekankan pada kegiatan dari orang-orang dalam hubungan dengan kerja atau kegiatan ekonomi. Selain itu juga angkatan kerja merupakan bagian dari tenaga kerja dan tenaga kerja merupakan bagian dari penduduk itu sendiri, sehingga secara struktural pertambahan tenaga kerja ataupun angkatan kerja tergantung pada pertumbuhan penduduk.

Angkatan kerja adalah: "Jumlah tenaga kerja yang sedang mencari pekerjaan (lapangan kerja) yang berusia antar 10 - 64 tahun." Sedangkan tenaga kerja adalah: “ Bagian dari angkatan kerja yang berfungsi ikut serta dalam proses produksi dan menghasilkan barang dan jasa."

Di dalam literatur ilmu ekonomi disebutkan bahwa akumulasi modal sangat diperlukan dalam proses pembangunan ekonomi suatu negara/daerah, terutama negara-negara yang sedang berkembang bahkan bahwa pembentukan modal atau investasi merupakan penentu utama pertumbuhan ekonomi. Menurut Richard T. Gill (1983) bahwa : "Modal sebuah negara adalah pemilikan atas saran-sarana produksi yang dihasilkan atau yang bikinan manusia, termasuk diantaranya barang-barang seperti antara lain : gedung-gedung, pabrik-pabrik, mesin-mesin, alat-alat dan perlengkapan serta persediaan barang-barang yang belum terjual."

Perlu diberikan catatan tentang pengertian modal disini, karena banyak istilah yang digunakan dengan arti yang berbeda yaitu :

1. Modal diberikan dalam pengertian barang-barang fisik yang nyata, jadi tidak mencakup uang, surat-surat berharga lainnya.

2. Modal dibedakan dari tanah dan tenaga kerja, karena itu kita menyebutnya sebagai dihasilkan atau bikinan manusia.

3. Modal dianggap sebagai suatu persediaan barang-barang dan bukannya sebagai suatu produksi sepanjang waktu. 
Menurut Richart T. Gill (1983) ada beberapa alasan sehingga pembentukan modal memegang peranan penting dalam mendorong pertumbuhan ekonomi suatu negara:

1. Investasi dalam peralatan modal tidak saja meningkatkan produksi tetapi juga kesempatan kerja. Pembentukan modal menghasilkan kemajuan teknis yang menunjang tercapainya ekonomi produksi skala luas dan meningkat spesialisasi, pembentukan modal memberikan mesin, alat dan perlengkapan bagi tenaga kerja yang semakin menguat. Jadi pembentukan modal juga menguntungkan buruh. Oleh karena itu investasi memainkan peranan ganda dalam meningkatkan hasil sesuatu sistim ekonomi yaitu terjadinya produksi secara besar-besaran dan spesialisasi yang meluas dan meningkatkan kemajuan teknologi.

2. Pembentukan modal menciptakan perluasan pasar, yaitu melalui penciptaan over head social dan ekonomi, ketidaksempurnaan pasar dapat disingkirkan.

3. Pembentukan modal membuat pembangunan menjadi mungkin dilakukan walau dengan penduduk yang meningkat. Dengan investasi maka produksi dapat ditingkatkan dan kesempatan kerja dapat diperluas, sehingga penduduk yang meningkat itu dapat diatasi.

4. Pembentukan modal domestik dapat memecahkan kesulitan neraca pembayaran. Dengan investasi yang besar maka industri pengganti import dapat didirikan sehingga import barang-barang tersebut dapat diganti.

5. Pembentukan modal pada kenyataannya membantu tercapainya swasembada suatu negara dan mengurangi beban utang luar negeri, laju pembentukan modal yang cepat, lambat laun akan mengurangi beban utang luar negeri, laju pembentukan modal yang cepat, lambat laun akan mengurangi kebutuhan modal asing.

\section{METODE}

\section{Identifikasi Variabel}

Untuk keperluan pembahasan skripsi ini, maka data yang akan dikumpulkan terdiri dari data mengenai jumlah tenaga kerja pada proyek PMDN, Jumlah Proyek PMDN dan kapasitas produksi $\left(\mathrm{M}^{3}\right)$ proyek PMDN. serta melihat besarnya penambahan jumlah proyek serta kapasitas proyek-proyek PMDN dengan penyerapan tenaga kerjanya di Propinsi Maluku dengan menggunakan teknik analisa Cobb Douglas. 


\section{Sumber Data}

Data yang diperoleh untuk penulisan skripsi ini diperoleh dari :

1. BKPMD Propinsi Maluku..

2. Statistik Tk. II Kota Ambon.

3. Dinas Tenaga Kerja dan Transmigrasi Propinsi Maluku.

\section{Teknik Pengambilan Data}

Penulisan ini menggunakan data sekunder, oleh karena itu data yang yang dikumpulkan adalah data yang sudah dipakai dan diolah oleh instansi-instansi yang bersangkutan dalam bentuk laporan bulanan, berkala, tahunan maupun terbitan (publikasi). Metode yang digunakan dalam penelitian untuk mengumpulkan data adalah :

1. Library research (penelitian kepustakaan) yaitu dengan mempelajari buku-buku dan laporan-laporan penelitian yang relevan dengan penulisan ini untuk memperluas wawasan teori, memperoleh pengetahuan dengan cara-cara membuat laporan penelitian. Dalam upaya memperoleh data sekunder maka sumber data yang digunakan berasal dari Kantor Gubernur Propinsi Maluku, Kantor BPS Kota Ambon serta dari Dinas Tenaga Kerja dan Transmigrasi Propinsi Maluku.

2. Alat dan teknis pengumpulan data dan hal lain yang berhubungan.

\section{Metode Analisis}

Analisis Kuantitatif yaitu melihat besarnya hubungan penambahan jumlah proyek serta kapasitas proyek-proyek PMDN dengan penyerapan tenaga kerja maka digunakan model Cobb Douglas yang kemudian ditranformasikan ke dalam persamaan linear menarik logaritma alam yaitu :

$$
\begin{aligned}
\operatorname{Ln} Y= & b_{0}+b_{1} \operatorname{Ln} X_{1}+b_{2} \operatorname{Ln} X_{2} \\
\text { dimana : } & \\
\operatorname{Ln} Y= & \text { Jumlah tenaga kerja pada proyek PMDN } \\
\operatorname{LnX}= & \text { Jumlah proyek PMDN } \\
\operatorname{LnX}_{2}= & \text { Jumlah kapasitas produksi }\left(M^{3}\right) \text { proyek PMDN } \\
b_{0}= & \text { Intersept } \\
b_{1} \quad= & \text { Elastisitas penambahan tenaga kerja dari penambahan jumlah } \\
& \text { proyek PMDN }\left(X_{1}\right) . \\
= & \text { Elastisitas penambahan tenaga kerja dari penambahan } \\
b_{2} \quad & \text { kapasitas produksi }\left(X_{2}\right) .
\end{aligned}
$$




\section{HASIL DAN PEMBAHASAN}

\section{Analisis Perkembangan Proyek PMDN di Propinsi Maluku}

Realisasi proyek PMDN/PMA sampai dengan tahun 2008 menunjukan penurunan, kecuali dalam dua tahun terakhir (2009-2010). Penurunan ini disebabkan karena telah selesai masa kontrak, krisis moneter, kerusuhan yang bernuansa SARA serta kemacetan karena kurangnya komunikasi serta perhubungan yang baik.

Pada tahun 2005 jumlah bidang usaha/jenis usaha yang dikelola proyek PMDN di daerah Maluku sebanyak 7 jenis, dengan 95 proyek atau 84,07\% yang terealisasi dari 113 proyek yang direncanakan. Masing-masing proyek ini antara lain adalah bidang usaha perikanan 7 proyek, kehutanan 10 proyek, industri makanan sebanyak 10 proyek, industri kayu 23 proyek, industri kimia 3 proyek, pengangkutan 20 proyek, dan jasa lainnya 22 proyek. Di tahun 2006 terjadi penurunan pada semua bidang usaha, sehingga jumlah proyek yang tercapai hanya 73 proyek dari 129 target proyek (56,58\%). Rendahnya angka realisasi proyek dibandingkan tahun 2005 disebabkan karena pada tahun 2006 terjadi krisis moneter dan ekonomi di Indonesia dan ini berdampak pada seluruh aspek ekonomi. Krisis ini melanda dan memukul hampir seluruh industri yang berdampak pada realisasi investasi baik PMA maupun PMDN. Krisis moneter ini juga turut dirasakan di Propinsi Maluku, dimana dari 129 target proyek PMDN yang terealisasi hanya 73 proyek $(56,58 \%)$.

Selain itu rendahnya realisasi pencapaian target yang dilakukan proyek PMDN ini disebabkan karena lambatnya proses perizinan penanaman modal yang antara lain berupa izin bangunan, izin UUG, izin HBB serta izin ABU di bawah $100 \mathrm{Ha}$. Dan dari berbagai perizinan yang ada, pengadaan dan penyiapan lahan yang membutuhkan waktu lama di samping itu juga faktor modal merupakan salah satu faktor yang turut mempengaruhi perkembangan proyek. 
Tabel 1.

Perkembangan Kapasitas Produksi Pada Proyek PMDN di Propinsi Maluku Tahun 2005 - 2010

\begin{tabular}{ccc}
\hline Tahun & $\begin{array}{c}\text { Kapasitas } \\
\left(\text { Unit/Ton/M } \mathbf{M}^{3}\right.\end{array}$ & $\begin{array}{c}\text { Perkembangan } \\
(\%)\end{array}$ \\
\hline 2005 & 1.347 .000 & - \\
2006 & 1.083 .000 & $-19,66$ \\
2007 & 973.000 & $-10,16$ \\
2008 & 781.000 & $-19,73$ \\
2009 & 752.000 & $-3,71$ \\
2010 & 836.000 & 11,17 \\
\hline
\end{tabular}

Sumber : BKPMD Propinsi Maluku

Tabel diatas maka pada tahun 2005 jumlah kapasitas produksi adalah sebesar 1.347.000 satuan, dan mengalami penurunan di tahun 2006 menjadi 1.083 .000 satuan atau turun sebesar -19,66\%. Pada tahun 2007 kembali kapasitas produksi mengalami penurunan menjadi 973.000 satuan atau turun sebesar $-10,16 \%$. Pada tahun 2008 kembali terjadi penurunan kapasitas produksi menjadi 781.000 satuan atau turun sebesar -19,73. Selanjutnya pada tahun 2009 kembali kapasitas produksi mengalami penurunan menjadi 752.000 satuan atau turun sebesar $-3,71 \%$. Pada tahun 2010 kapasitas mengalami peningkatan sebesar 836.000 satuan atau naik sebesar $11,17 \%$. Ini merupakan angka positif yang dicapai oleh pemerintah Propinsi Maluku dalam 6 tahun terakhir pasca krisis moneter dan kerusuhan yang bernuansa SARA di Maluku. Berdasarkan perkembangan tersebut rata-rata persentase penurunan kapasitas produksi dari proyek PMDN di Daerah Maluku selama tahun 2005 -2010 adalah sebesar $-8,87 \%$ per tahun.

\section{Analisis Perkembangan Tenaga Kerja}

Jumlah tenaga kerja asing yang terserap pada proyek PMDN di Daerah Maluku sampai dengan tahun 2010 adalah 144 orang, dan tersebar pada beberapa sektor/bidang usaha antara lain: perikanan 23 orang, kehutanan 11 orang, industri kayu 105 orang, industri kimia 2 orang dan galangan kapal sebanyak 3 orang. Sedangkan untuk sektor atau bidang usaha lainnya tidak digunakan tenaga kerja asing. Jumlah tersebut apabila dibandingkan dengan banyaknya perusahaan PMDN yang beroperasi di Daerah Maluku maka dapat dikatakan bahwa dari 174 perusahaan yang diantaranya hanya 13 perusahaan yang mendapat ijin kerja tenaga kerja asing. Jumlah tenaga kerja asing tersebut di atas apabila dikelompokan berdasarkan jabatan maka sebanyak 142 orang bekerja sebagai teknisi dan 2 orang sisanya sebagai manejer. 
Hal ini disebabkan karena jenis usaha untuk proyek-proyek tersebut masih dibutuhkan tenaga kerja teknisi yang profesional dari luar karena tenaga kerja kita belum secara baik dapat menguasai bidang tersebut. Namun demikian yang terserap pada proyek PMDN dari tahun ke tahun terus menunjukan penurunan kecuali pada tahun 2010 yang cukup meningkat seiring dengan perkembangan sektor serta jumlah perusahaan PMDN yang beroperasi. Menyangkut perkembangan jumlah tenaga kerja pada proyek PMDN yang beroperasi di Daerah Maluku lebih jelas dapat dilihat pada Tabel 2:

Tabel 2.

Perkembangan Jumlah Tenaga Kerja Pada Proyek PMDN Di Propinsi Maluku Tahun $2005-2010$

\begin{tabular}{ccc}
\hline Tahun & $\begin{array}{c}\text { Tenaga Kerja } \\
\text { (orang) }\end{array}$ & $\begin{array}{c}\text { Perkembangan } \\
(\%)\end{array}$ \\
\hline 2005 & 23.400 & - \\
2006 & 21.394 & $-8,57$ \\
2007 & 13.767 & $-36,07$ \\
2008 & 8.740 & $-36,09$ \\
2009 & 8.430 & $-3,46$ \\
2010 & 9.821 & 17,75 \\
\hline
\end{tabular}

Sumber : BKPMD Propinsi Maluku

Berdasarkan data pada tabel di atas maka terlihat bahwa jumlah tenaga kerja yang terserap pada proyek PMDN terus menurun pada lima tahun terakhir dan pada tahun 2010 menunjukan peningkatan yang sangat signifikan yaitu $17,75 \%$. Penurunan ini disebabkan karena adanya penurunan dalam jumlah proyek yang beroperasi pada tahun-tahun tersebut. Pada tahun 2005 jumlah tenaga kerja yang terserap adalah sebanyak 23.400 orang. Jumlah ini kemudian mengalami penurunan pada tahun 2006, dimana tenaga kerja yang terserap sebanyak 21.394 orang atau menurun $8,57 \%$. Pada tahun 2007 kembali tenaga kerja mengalami penurunan menjadi 13.676 orang atau turun sebesar $36,07 \%$.

Di tahun 2008 kembali tenaga kerja mengalami penurunan yang tertinggi menjadi 8.740 orang atau turun sebesar 36,09\%. Pada tahun 2010 jumlah tenaga kerja mengalami peningkatan dalam penyerapannya pada proyek PMDN menjadi 9.821 orang atau naik menjadi $17,75 \%$. Hal ini sebagai akibat dari meningkatnya jumlah proyek yang ada maka jumlah tenaga kerja mengalami peningkatan 9.821 orang dibandingkan dengan tahun 2009.

Berdasarkan perkembangan jumlah tenaga kerja yang terserap pada proyek PMDN maka diperoleh rata-rata persentase penurunan per tahun, selama tahun $2005-2010$ adalah sebesar $-11,07 \%$. Hal ini menggambarkan bahwa penyerapan tenga kerja 
sangat dipengaruhi oleh perkembangan jumlah proyek serta kapasitas produksi dari proyek PMDN tersebut. Dan menyangkut besarnya pengaruh jumlah proyek serta kapasitas produksi terhadap penyerapan tenaga kerja pada proyek PMDN di Daerah Maluku secara terperinci akan diuraikan dalam sub bab berikut ini.

\section{Analisa Pengaruh Proyek PMDN dan Kapasitas Produksi PMDN.}

Dimuka telah diuraikan tentang perkembangan proyek PMDN serta kapasitas produksi yang terpasang dan perkembangan penyerapan tenaga kerja pada proyek-proyek tersebut, maka pada bagian ini akan dibahas menyangkut pengaruh antara ketiga variabel tersebut dan sekaligus membuktikan hipotesis yang telah dirumuskan sebelumnya dengan menggunakan alat analisa statistik yaitu fungsi Produksi Cobb Douglas. Namun sebelum disajikan hasil penelitian empiris atau hasil pengelolaan data, maka terlebih dahulu dikemukakan data yang digunakan dalam penelitian hipotesa tersebut, seperti tercantum pada Tabel 3.

Berdasarkan data yang dengan diolah kembali dengan menggunakan fungsi Produksi Cobb Douglas, yang dilinierkan dengan menggunakan logaritma, maka diperoleh nilai $b_{0}=1,78$, nilai $b_{1}=0,36$ dan nilai $b_{2}=1,82$. Sehingga persamaan linear diatas ditransformasikan menjadi :

$$
\operatorname{LnY}=1,78+0,36 \operatorname{Ln} X_{1}+1,82 \operatorname{Ln} X_{2} .
$$

Dari persamaan tersebut dapat dijelaskan sebagai berikut :

Nilai 0,36 yang berarti bahwa besar pengaruh penambahan proyek PMDN atau elastisitas penambahan proyek PMDN adalah sebesar 0,36. Hal ini berarti bahwa penambahan apabila kapasitas produksi $\left(X_{2}\right)$ tetap atau tidak berubah maka dengan peningkatan jumlah proyek PMDN $\left(\mathrm{X}_{1}\right)$ 1\%, akan menyebabkan terjadinya penambahan jumlah tenaga kerja $(\mathrm{Y})$ yang terserap pada proyek PMDN sebesar $36 \%$.

Tabel 4.

Jumlah Proyek, Kapasitas Produksi dan Penyerapan Tenaga Kerja Pada Proyek PMDN Di Provinsi MalukuTahun 2005 - 2010

\begin{tabular}{cccc}
\hline Tahun & $\begin{array}{c}\text { Jumlah Proyek } \\
\text { (Unit) } \\
\mathbf{X 1}\end{array}$ & $\begin{array}{c}\text { Kapasitas Produksi } \\
{\text { (Unit/Ton/ } \mathbf{M}^{\mathbf{3}} \text { ) }}_{\mathbf{X 2}}\end{array}$ & $\begin{array}{c}\text { Jumlah Tenaga Kerja } \\
\text { (Orang) } \\
\mathbf{Y}\end{array}$ \\
\hline 2005 & 95 & 1.347 & 23.400 \\
2006 & 73 & 1.083 & 21.394 \\
2007 & 11 & 973 & 13.676 \\
2008 & 9 & 781 & 8.740 \\
2009 & 14 & 752 & 8.430 \\
2010 & 16 & 836 & 9.821 \\
\hline
\end{tabular}

Sumber: BKPMD Propinsi Maluku 
Dengan demikian terdapat hubungan yang positif antara penambahan proyek PMDN dengan penyerapan tenaga kerja pada proyek tersebut, hal ini disebabkan karena sebagian proyek yang ada masih bersifat padat karya atau menggunakan jumlah tenaga kerja yang cukup besar, dan di samping itu juga salah satu tujuan dari pengembangan proyek PMDN ini adalah untuk perluasan kesempatan kerja sehingga bisa menyerap tenaga kerja.

Untuk itu maka dalam meningkatkan proyek PMDN ini maka perlu adanya upayaupaya yang dilakukan pemerintah berupa kemudahan pemberian ijin penanaman modal bagi pihak swasta, peningkatan kelancaran sarana prasarana transportasi dan komunikasi serta pengadaan promosi-promosi tentang pengenalan potensi daerah kepada para investor yang ada diluar daerah.

Nilai 1,82 menunjukan bahwa pengaruh penambahan kapasitas produksi terhadap penyerapan tenaga kerja adalah sebesar $18,2 \%$. Hal ini berarti bahwa apabila jumlah $\operatorname{PMDN}\left(\mathrm{X}_{1}\right)$ tidak berubah atau konstan maka dengan penambahan kapasitas produksi $\left(\mathrm{X}_{2}\right)$ sebagai perluasan produksi pada proyek yang telah ada sebesar $1 \%$, akan berpengaruh terhadap penyerapan tenaga kerja sebesar $18,2 \%$ atau dengan kata lain apabila $X_{1}$ konstan atau tidak berubah maka dengan penambahan $X_{2}$ sebesar $1 \%$ akan berpengaruh terhadap penyerapan tenaga kerja sebesar nilai $b_{2}$ menyebabkan peningkatan $\mathrm{Y}$ sebesar nilai $\mathrm{b}_{2}$.

Dari hasil perhitungan di atas terlihat hubungan positif antara penambahan kapasitas produksi dengan penambahan penyerapan tenaga kerja, hal ini disebabkan karena untuk menjalankan proses produksi tersebut maka sangat dibutuhkan tenaga kerja yang menggerakkan proses produksi yang dilaksanakan. Dengan demikian maka setiap penambahan kapasitas produksi dibutuhkan pula penambahan tenaga kerja. $b_{0}$ = 1,78 yang berarti bahwa apabila jumlah proyek PMDN $X_{1}$ dan kapasitas produksi $X_{2}$ tidak berubah atau konstan maka jumlah tenaga kerja yang terserap $Y$ adalah $8,2 \%$. Berdasarkan uraian di atas maka dapat dikatakan bahwa perkembangan jumlah proyek PMDN baik dalam jumlah maupun kapasitas produksi sangat mempengaruhi jumlah tenaga kerja yang terserap.

Selanjutnya untuk melihat keeratan hubungan serta pengaruh diantara penambahan proyek dan kapasitas produksi terhadap penyerapan tenaga kerja, maka sesuai dengan hasil perhitungan pada lampiran diperoleh hasil koefisien $\mathrm{R}$ sebesar 0,92 yang berarti bahwa adanya hubungan yang positif yang sangat erat antara penambahan 
jumlah proyek dan kapasitas produksi terhadap penyerapan tenaga kerja pada proyek PMDN. Sedangkan dari koefisien $R^{2}$ sebesar 0,95 menunjukkan bahwa 95\% penyerapan tenaga kerja dipengaruhi oleh penambahan kapasitas produksi. Sisanya $5 \%$ adalah dipengaruhi oleh faktor-faktor lain, yang dalam penulisan ini dianggap konstan.

Untuk membuktikan pengaruh antara masing-masing variabel maka digunakan pengujian tabel $t$ dengan menggunakan $=5 \%$ dan $D_{f}$ yang diperoeh dari $n=6$ dan $k=$ 3 yaitu 3,182 . Sesuai dengan hasil perhitungan penelitian hipotesis pada lampiran maka untuk pengujian tabel $t$ untuk melihat tingkat signifikan antara pengaruh jumlah proyek PMDN $\left(X_{1}\right)$ terhdap penyerapan tenaga kerja diperoleh t hitung 3,80. Dengan demikian $\mathrm{t}$ hitung lebih besar dari $\mathrm{t}$ tabel yang berarti ada hubungan signifikansi antara kedua variabel tersebut. Demikian pula dalam pengujian tingkat signifikansi antara variabel peningkatan kapasitas produksi $\left(\mathrm{X}_{2}\right)$ dengan variabel penyerapan tenaga kerja (Y) diperoleh nilai t hitung 3,87 dengan demikian $t$ hitung lebih besar dari t tabel yang berarti ada hubungan siginifikan yang positif pula diantara kedua variabel tersebut. Berdasarkan pengujian di atas maka hipotesa yang dikemukakan di muka yaitu 'Pengembangan jumlah proyek PMDN berpengaruh positif yang sangat erat terhadap penyerapan tenaga kerja di Maluku dapat diterima kebenarannya.

\section{SIMPULAN}

Penanaman Modal dalam Negeri (PMDN), merupakan investasi yang ditanamkan pada proyek-proyek swasta nasional dan merupakan dana pelengkap yang sangat dominan bagi pembangunan. Jumlah proyek Penanaman Modal Dalam Negeri pada daerah Maluku menunjukan suatu fluktuasi selama tahun 2005-2010. Di samping proyek penanaman modal dalam negeri berpengaruh langsung terhadap penambahan anggaran pembangunan, proyek Penanaman Modal Dalam Negeri (PMDN) juga sangat berpengaruh dalam membuka kesempatan kerja serta penyerapan tenaga kerja yang ada selama tahun 2005-2010, walaupun penyerapan menunjukan fluktuasi. Analisis kuantitatif menunjukan adanya hubungan yang positif antara penambahan proyek PMDN dan kapasitas produksi pada proyek tersebut dengan penyerapan tenaga kerja. Dari hasil perhitungan diperoleh nilai $R$ dan $R_{2}$ adalah sebesar 0,92 dan 0,95 yang berarti ada hubungan yang erat serta pengaruh positif diantara variabel proyek PMDN dan kapasitas produksi terhadap penyerapan tenaga kerja. Efek ganda yang dapat ditimbulkan dari adanya proyek PMDN ini adalah disamping dapat membuka kesempatan kerja, juga turut mengembangkan daerah yang berada di 
sekitar lokasi proyek dengan turut berpartisipasi dalam pembangunan desa dan menyediakan fasilitas umum seperti : listrik, jalan-jalan yang bisa dinikmati oleh masyarakat dan lainnya.

\section{PUSTAKA ACUAN}

Departemen Penerangan. 1985. Pembangunan Transmigrasi di Indonesia, Jakarta.

Esmara, Henra. 1981. Proyeksi Kesempatan Kerja Dalam Pelita IV, Jakarta.

Gill, Richard T. 1983. Ekonomi Pembangunan Dulu dan Sekarang. Terjemahan: Aminudin, Bogor : Ghalia Indonesia.

Irwan dan Soeparmoko. 1987. Ekonomi Pembangunan. Edisi ke - 4, Yogyakarta : Penerbit Liberthy.

Jhinghan, M.L. 2000. Ekonomi Pembangunan dan Perencanaan. Jakarta : PT. Raja Grafindo.

Lembaga Demografi FE - UI. 1980. Buku Kependudukan, Jakarta. LD FE-UI.

Payaman J. Simanjuntak. 1990. Pengantar Ekonomi dan Sumber Daya Manusia.

Soeroto. 1983. Strategi Pembangunan dan Perencanaan Tenaga Kerja. Yogyakarta UGM.

Squire, Lyn. 1982. Kebijaksanaan Tenaga Kerja di Negara Yang Sedang Berkembang. Jakarta : Penerbit UI dan Pustaka Bjadagna.

Sukirno, Sadono. 1985. Ekonomi Pembangunan, Proses Masa dan Kebijaksanaan. Jakarta : Lembaga Fakultas FE - UI dan Bina Grafika.

Swasono, Yudo. 1982. Perencanaan Tenaga Kerja di Indonesia. Jakarta : Prisma No. 14.

Tjiptoherijanto, Prijono. 1984. Peningkatan Pendekatan Melalui Peningkatan Kualitas Penduduk: Suatu Renungan. Jakarta: Demografi, No. 21. 